Acta regionalia et environmentalica 2

Nitra, Slovaca Universitas Agriculturae Nitriae, 2013, p. 34-37

\title{
INCREASE OF BIOMASS PRODUCTION OF FAST-GROWING WILLOWS IN THE FIRST YEAR OF THE SECOND HARVEST CYCLE
}

\author{
Martin HAUPTVOGL
}

Slovak University of Agriculture in Nitra, Slovakia

\begin{abstract}
The aim of the paper is to evaluate biomass production of three different willow varieties (Salix spp.) at the end of the first year of the second harvest cycle (2012) and to compare the results with those obtained in the first harvest cycle at the end of the first growing season after cutback (2008). The observed growth parameters included number of shoots per plant, shoot height and diameter, and weight of fresh matter per plant. Three willow varieties were studied (Tora, Gudrun and Tordis). The individual growth parameters were determined by destructive method. The number of the shoots per plant varied from 17.83 (Tora) to 30.17 (Gudrun). The shoot height ranged from $2.66 \mathrm{~m}$ (Gudrun) to $3.62 \mathrm{~m}$ (Tordis) and the shoot diameter ranged from $10.85 \mathrm{~mm}$ (Gudrun) to $13.14 \mathrm{~mm}$ (Tordis). The variety with the greatest biomass production of the fresh above-ground matter was Tora (5.43 kg plant $\left.{ }^{-1}\right)$, followed by Gudrun $\left(4.97 \mathrm{~kg} \mathrm{plant}^{-1}\right)$. Tordis provided the lowest yield $\left(4.55 \mathrm{~kg} \mathrm{plant}^{-1}\right)$. All of the observed growth parameters had higher values than those determined at the end of the first year after cutback in the first harvest cycle. The most significant increase was recorded in the above-ground biomass production with the percentage increase of $114 \%, 122 \%$ and $226 \%$ in Tora, Tordis and Gudrun, respectively.
\end{abstract}

Keywords: biomass production, fast-growing willow, growth parameter, Salix spp.

In Europe, biomass and waste are the most important sources of renewable energy, accounting for $67.7 \%$ of primary renewable production in 2009 (EUROSTAT, 2012). In this sense, purpose-grown fast-growing woody crops represent a promising source of renewable energy. The energy potential of purpose-grown biomass in Slovakia is 32 PJ (TSÚP 2007). This amount represents $4 \%$ of the total annual consumption, which is $800 \mathrm{PJ}$ (TSÚP 2010). Therefore, this energy source can be seen as a local, mostly suitable for single households or small communities. The biomass of the fast growing perennial plants and trees can be used, except of direct combustion, for production of methane, ethanol and biodiesel (Herrera, 2006). Production of ethanol from perennial plants and trees (second generation) is more efficient from the soil use point of view than from annual plants of the first generation (ex. maize and sugarcane) (Graham et al., 1995). There is a wide range of environmental advantages of biomass production from perennials instead of annual plants (Kägi et al., 2008; Rowe et al., 2009). The whole life cycle of energy production, from the plantation establishment to energy distribution, can be interesting for many regions, especially in rural areas in terms of job creation.

There is a wide variety of fast growing woody crops that can be grown for energy purposes. Willows and poplars are considered as the most suitable for Slovak conditions (other feasible species include ailanthus, elm, rose, alder, linden, hazel, rowan, birch, and larch) (Jandačka et al., 2007). First plantations of short rotation coppice (SRC) willow for energy purposes were established in 1970s in Sweden (Christensson et al., 1993). The research of the SRC willow in Slovakia has begun in 1994, when the first experimental plantations consisted of Swedish willow varieties were established in Krivá na Orave in northern Slovakia (Habovštiak and Daniel, 2001). The first field trial of SRC willow at Slovak University of
Agriculture (SUA) has begun in 1996 with the establishment of experimental base in Malanta (Húska, 2000).

The most crucial factor of commercial plantations is the amount of above-ground biomass production. It is therefore very important to study growth patterns of these crops and capability of their adaptation into various climate conditions. Willow (Salix spp.) has several characteristics that make it a suitable woody crop for biomass production. It is characterised by the ability to provide maximum annual growth and great amount of biomass already in few years after planting. Willow is tolerant to high planting densities and is able to reproduce fast and regrow after coppicing (cutting) few centimetres above soil surface (Keolian and Volk, 2005). The complex review of basic ecophysiology of short rotation forest crops is provided by Mitchell et al. (1992). Experimental studies show that willows are able to provide considerably higher biomass production in the second rotation cycle compared to the first rotation cycle (Jug et al., 1999).

The aim of the paper is to evaluate biomass production of three willow varieties at the end of the first growing season of the second harvest cycle and compare the results with the biomass production provided by one-year-old shoots at the end of the first growing season (after cutback) of the first harvest cycle.

\section{Material and methods}

The research was carried out in a willow plantation established in 2007 in Kolínany in south-western Slovakia $\left(48^{\circ} 21^{\prime} 20^{\prime \prime} \mathrm{N}, 18^{\circ} 12^{\prime} 23^{\prime \prime} \mathrm{E}\right)$. The altitude of the site is $180 \mathrm{~m}$ a.s.l. The area belongs to warm, very dry and lowland climatic regions. The sum of average daily temperatures above $10^{\circ} \mathrm{C}$ is $3000-2800{ }^{\circ} \mathrm{C}$. The number of days with air temperature 
above $5^{\circ} \mathrm{C}$ is 237 . The average annual temperature is $9.9^{\circ} \mathrm{C}$. The long-term (1991-2000) average rainfall is $547.6 \mathrm{~mm}$ (measured in Nitra, located $13 \mathrm{~km}$ from the site) (Špánik et al., 2008). The whole area is plain with no occurrence of surface water erosion $\left(0^{\circ}-1^{\circ}\right)$. There is a stream Bocegaj in the close vicinity of the plantation, so the underground water level is relatively high. Soils are deep (60 cm or more), without skeleton. The main soil type consists of gley fluvisol. In terms of soil grain structure, it is moderately heavy (loam) soil (Linkeš et al., 1996).

Soil $\mathrm{pH}$ values ranged from 7.18 to 7.35 and humus content was 1.16 to $2.50 \%$ (Hauptvogl, 2011). The studied willow varieties originate from Swedish breeding program. The planting material $(20 \mathrm{~cm}$ long one-year-old willow cuttings) was provided by company Lantmännen Agroenergi (former Agrobränsle). Three willow varieties were studied: Tora, Gudrun and Tordis. Tora (Salix schwerinii $\times$ S. viminalis) is a cross between a Siberian basket willow and the variety Orm. Gudrun (Salix dasyclados) is a hybrid between the Russian variety Helga and the clone LångaVeka Röd from Sweden. Tordis ((Salix schwerinii $\times$ S. viminalis $) \times$ S. viminalis) is a cross between the varieties Tora and Ulv (Agrobränsle 2006). The varieties were planted in double-rows with the distance between the double-rows of $1.5 \mathrm{~m}$. The distance between rows within the double-row was $1.0 \mathrm{~m}$ and the distance between individual plants in the row was $0.75 \mathrm{~m}$. This design represents density of 10,666 plants ha ${ }^{-1}$.

The measurements of the growth parameters were taken at the end of the growing seasons 2008 and 2012. The results from 2008 represent biomass production of the second year after the planting. As well as in 2012, it is a production of one-year-old shoots, because there was a cutback at the end of the first year of the plantation establishment. The measurements were provided on six plants from each variety that were chosen randomly from four replicating plots. All shoots per plant were measured and weighed individually. The methodology of measurements is described by Hauptvogl (2011), Bako (2012) and Husár (2013).

Single-factor analysis of variance (ANOVA) was used for the statistical evaluation of the growth parameters studied in 2012.

\section{Results and discussion}

In terms of total annual precipitation, the growing year 2008 can be characterized as normal. The total precipitation was $529.4 \mathrm{~mm}$. A significant difference compared to long-term normal was observed in August, which was extremely dry (the amount of precipitation was 5 times lower than normal). The average annual air temperature was $11.2{ }^{\circ} \mathrm{C}$ (data provided by SHMÚ 2010). The annual total amount of precipitation in 2012 was $467 \mathrm{~mm}$, which is $79.7 \mathrm{~mm}$ less than long-term normal. Months March $(2.8 \mathrm{~mm})$ and August $(7.3 \mathrm{~mm})$ were extremely dry; while October $(76.1 \mathrm{~mm})$ was very wet (data provided by Gabčo, 2013).

The growth parameters of the three willow varieties were observed at the end of the growing year 2012. The measurements were taken on one-year-old shoots of shrubs with six-year-old root system. The results were compared

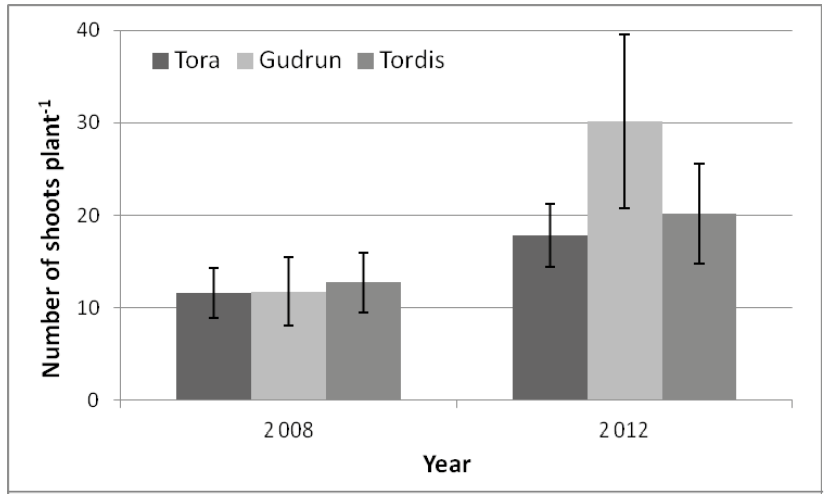

Figure 1 The comparison of the number of shoots between the growing seasons of 2008 and 2012

with one-year-old shoots of shrubs with two-year-old root system. In our study, we did not observe the size of the root system. According to Stephens et al. (2001), the roots of the mature willow stand can reach to a depth of $2.5 \mathrm{~m}$ (Stephens et al., 2001). Therefore, it plays a significant role in biomass growth and development.

The biggest number of shoots per plant was provided by Gudrun (30.17), followed by Tordis (20.17) and Tora (17.83) (Fig. 1). The differences among the varieties were statistically significant (Tab. 1). In 2012, Gudrun had an increase of $157 \%$ in the number of shoots compared to 2008. Though Gudrun did not have the highest average number of shoots in 2008 , it surpassed the other varieties in the subsequent year (Fazekaš 2011, Hauptvogl 2011). Gudrun had the highest number of shoots compared to the other varieties in another research plantation in south-western Slovakia (Selice) at the end of the first year after planting (Skladan 2011) and during the whole first harvest cycle (Hauptvogl 2011). These numbers are much higher than those observed by Stackevičienê et al. (2010) in the same varieties grown on sod-podzolic sandy loam soil in Lithuanian condition. The general characterisation of these varieties studied in UK conditions also does not indicate that their number of shoots should exceed 6 shoots plant ${ }^{-1}$ in Tora and Tordis and 8 shoots plant ${ }^{-1}$ in Gudrun (Caslin et al., 2012).

The highest shoots were measured in Tordis (3.62 m) and Tora $(3.50 \mathrm{~m})$. Gudrun had the lowest shoot height $(2.66 \mathrm{~m})$, which was almost $1 \mathrm{~m}$ lower than in Tordis. Similar order of the shoot heights was observed also in 2008 with Tora and Tordis having the highest shoots and Gudrun the lowest shoots (Fig. 2). The percentage increase of shoot heights in 2012 was $29 \%, 31 \%$ and $38 \%$ in Tora, Gudrun and Tordis, respectively. The shoot heights observed in our conditions in both studied years were lower than typical heights obtained in the UK conditions, which are $4 \mathrm{~m}, 4 \mathrm{~m}$ and $2.7 \mathrm{~m}$ for Tora, Tordis and Gudrun, respectively in the first year after cutback of the first rotation cycle (Caslin et al., 2012).

Similarly to shoot heights, the shoot diameters measured in our conditions were lower in both studied years than typical values in the UK conditions. These are $1.6 \mathrm{~cm}$ in all studied varieties measured at $1 \mathrm{~m}$ in the first year after cutback (Caslin et al., 2012). In our conditions, Tordis had the highest values of the shoot diameter $(13.14 \mathrm{~mm})$ as well as the highest percentage increase in shoot diameter (35\%) compared to 2008. The order of the other two varieties was 
Table 1 Single-factor analysis of variance (ANOVA) of the studied growth parameters among individual willow varieties (level of significance is defined as: $\mathrm{n}$ : non-significant impact, + : significant impact in $P \leq 0.05,++: P \leq 0.01$ and $+++: P \leq 0.001$ )

\begin{tabular}{|l||c|c|c|c|}
\hline Growth parameter & F & P value & F critical & Significance (2) \\
\hline \hline Number of shoots & 5.957337 & 0.012467 & 3.68232 & + \\
\hline Shoot height & 15.74142 & 0.000207 & 3.68232 & +++ \\
\hline Shoot diameter & 4.760919 & 0.030048 & 3.885294 & + \\
\hline Weight of the fresh biomass & 0.233767 & 0.794376 & 3.68232 & $\mathrm{n}$ \\
\hline
\end{tabular}

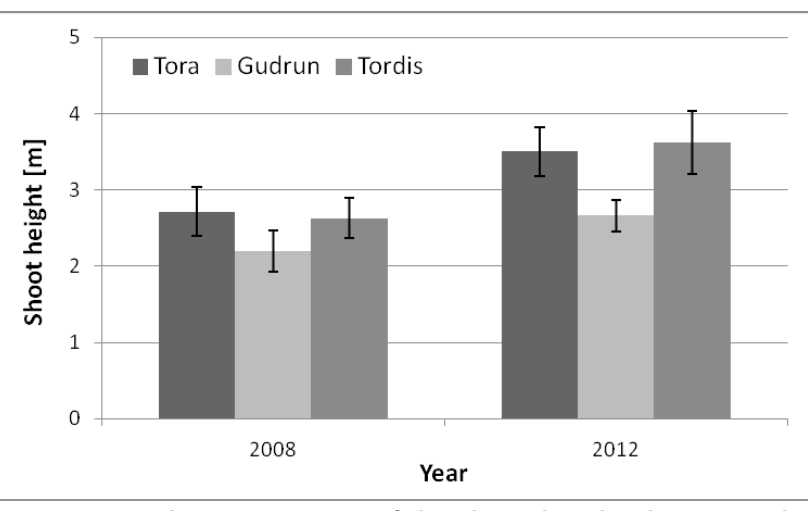

Figure 2 The comparison of the shoot heights between the growing seasons of 2008 and 2012

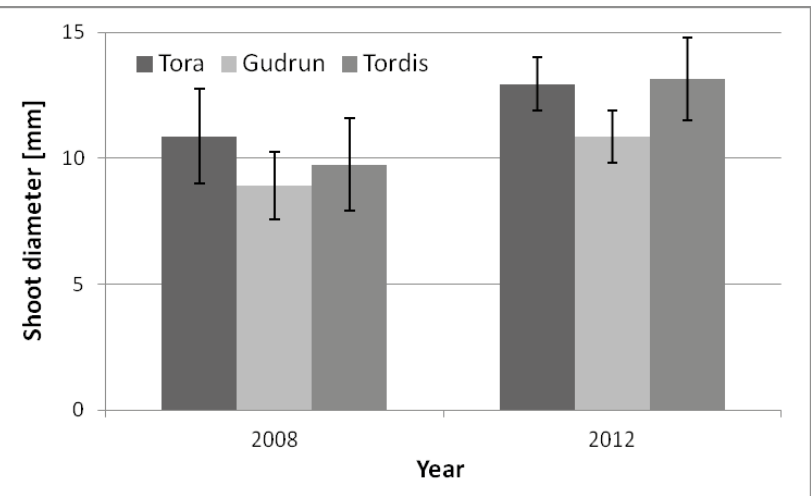

Figure 3 The comparison of the shoot diameters between the growing seasons of 2008 and 2012

the same as in the shoot height, with Gudrun having the smallest shoot diameter (10.85 mm) (Fig. 3). The differences among the varieties in shoot heights and diameters in 2012 were statistically significant (in case of shoot heights highly significant) (Tab. 1).

The highest biomass yield was provided by Tora $(5.43 \mathrm{~kg}$ plant $\left.^{-1}\right)$. Tora had the highest yield also in $2008(2.54 \mathrm{~kg}$ plant $\left.^{-1}\right)$. The percentage increase represents $114 \%$. The highest increase in biomass yield was observed in Gudrun. The biomass production was more than twice the value obtained in the one-year-old stand in the first harvest cycle (226\%). This high yield was due to great number of shoots per plant. Tordis had the lowest biomass yield ( $\left.4.55 \mathrm{~kg} \mathrm{plant}^{-1}\right)$ with the percentage increase of $122 \%$. It was reported that willows are able to increase their biomass production by $33-400 \%$ in the second harvest cycle (Jug et al., 1999). There was no statistically significant difference in the biomass production among the varieties in 2012 (Tab. 1).

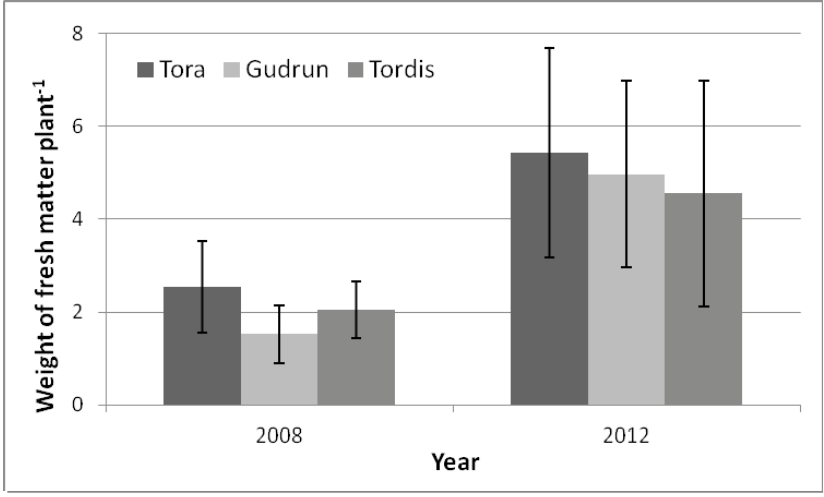

Figure 4 The comparison of the fresh biomass production between the growing seasons of 2008 and 2012

\section{Conclusion}

There was an increase recorded in all of the observed growth parameters between the growing seasons 2008 and 2012. This is due to much more developed root system in the first year of the second harvest cycle. The highest number of shoots per plant was observed in variety Gudrun (30.17) and the lowest in Tora (17.83). Despite having the lowest number of shoots, Tora provided the highest biomass yields (5.43 kg plant $\left.{ }^{-1}\right)$. The highest values both in shoot heights and diameters were found in variety Tordis. However, Tordis provided the lowest biomass yield $\left(4.55 \mathrm{~kg} \mathrm{plant}^{-1}\right)$. Due to the great number of shoots, Gudrun surpassed Tordis in biomass production at the end of the growing season of 2012 and provided $4.92 \mathrm{~kg} \mathrm{plant}^{-1}$. Gudrun had the highest percentage increase in biomass production, which was more than twice the amount obtained in 2008 (226\%). The growth parameters among the studied varieties in 2012 were statistically significant, except for the biomass production. In conclusion, we can say that the most productive variety in both harvesting cycles was Tora. Even though the differences in biomass production among the studied varieties were not statistically significant, the results indicate that Tora is the most suitable variety for biomass production in our conditions.

\section{Acknowledgment}

The paper was supported by the Ministry of Education, Science, Research and Sport of the Slovak Republic under the Project VEGA No.: 1/0942/12: “Varietal dependency of production and energy potential of fast-growing woody plants of genus Salix and Populus in the first and second three-year harvest cycles and energy grass Miscanthus in agro-climatic conditions of south-western Slovakia". 


\section{References}

AGROBRÄNSLE. 2006. Agrobränsle Willow Varieties. [on-line]. [cit. 2013-06-06]. Available at: < http://pohjonen.org/veli/ vpapps/2006-agrob-salix-varieties.pdf>.

BAKO, A. 2012. Odrodová podmienenost' tvorby biomasy rýchlorastúcich energetických drevín rodu Salix v pôdnoekologických podmienkach juhozápadného Slovenska: dizertačná práca. Nitra : SPU, 2012, $158 \mathrm{~s}$.

CASLIN, B. - FINNAN, J. - MCCRACKEN, A. (eds.). 2012. Willow Varietal Identification Guide. [on-line]. [cit. 2013-27-06]. Available at: <http://www.teagasc.ie/publications/2012/1494/ Willow_Identification_Guide_2012.pdf >.

CHRISTENSSON, L. et al. 1993. The role and significance of woody biomass plantations in Swedish agriculture. In The Forestry Chronicle, vol. 69, 1993, no. 6, pp. 687-693.

EUROSTAT. 2012. Europe in figures: Eurostat yearbook 2012 [online] [cit. 2013-20-06]. Available at: <http://epp.eurostat. ec.europa.eu/cache/ITY_OFFPUB/KS-CD-12-001/EN/KS-CD-12001-EN.PDF>.

GABČO, J. 2013. Priemerné ročné teploty a úhrny zrážok v roku 2012 na lokalite Malanta [elektronická pošta]. Správa pre: Martin Hauptvogl. 2013-04-03 [cit. 2010-05-07]. Osobná komunikácia

GRAHAM, R. L. - LIU, W. - ENGLISH, B. C. 1995. The Environmental Benefits of Cellulosic Energy Crops at a Landscape Scale. In Environmental Enhancement Through Agriculture: Proceedings of a Conference. Boston, Massachusetts : Tufts University, Medford, MA., 1995. p. 225-234.

HABOVŠTIAK, J. - DANIEL, J. 2001. Pestovanie odrôd vŕby (Salix viminalis) na energetické účely. In Naše pole, roč. 5, 2001, č. 5, s. 10.

HAUPTVOGL, M. 2011. Vlpyv pôdno-klimatických a hydrologických podmienok juhozápadného Slovenska na vybrané produkčné ukazovatele rýchlorastúcej energetickej dreviny rodu Salix): dizertačná práca. Nitra : SPU, 2011, 119 s.

HERRERA, S. 2006 Bonkers about biofuels. In Nature biotechnology, vol. 24, 2006, no. 7, pp. 755-760.

HUSÁR, L. 2013. Sledovanie vybraných rastových parametrov v poraste rýchlorastúcich vŕb $\mathrm{v}$ druhom zberovom cycle: diplomová práca. Nitra : SPU, 2013, $60 \mathrm{~s}$.

HÚSKA, J. et al. 2000. Experimentálne výsledky z pestovania vŕby košikárskej (Salix viminalis). Proceedings of the International Conference. Bratislava : DATAEXPRES, 2000, pp. 124-128.

JANDAČKA, J. - MALCHO, M. - MIKULÍK, M. 2007. Biomasa ako zdroj energie: Potenciál, druhy, bilancia a vlastnosti palív. In: Juraj Štefuň - GEORG, 2007, 241 s. ISBN 978-80-969161-3-9.

JUG, A. et al. 1999. Short-rotation plantations of balsam poplars, aspen and willows on former arable land in the Federal Republic of Germany. II. Nutritional status and bioelement export by harvested shoot axes. In Forest Ecology and Management, vol. 121,1999, no. $1-2$, pp. 67-83.
KÄGl, T. et al. 2008. Environmental impacts of annual and perennial energy crops compared to a reference food crop rotation. In Empowerment of the rural actors: A renewal of the farming systems perspective: Proceedings of $8^{\text {th }}$ European IFSA Symposium. Clermont-Ferrand: INRA SAD, Thivernal Grignon, 2008, pp. 675-681. ISBN 978-2-7380-1252-4.

KEOLEIAN G. A. - VOLK, T. A. 2005. Renewable Energy from Willow Biomass Crops: Life Cycle Energy, Environmental and Economic Performance. In Critical Reviews in Plant Sciences, vol. 24, 2005, no. 5-6, p. 385- 406.

LINKEŠ, V. - PESTÚN, V. - DŽATKO, M.1996. Príručka pre používanie máp bonitovaných pôdno-ekologických jednotiek. 3. vyd. Bratislava : Výskumný ústav pôdnej úrodnosti, 1996, 104 s. ISBN 80-85361-19-1. [on-line] [cit. 2013-03-05]. Available at: <http://www.podnemapy.sk/portal/verejnost/bpej/ priruckaBPEJ.pdf>.

MITCHELL, C. P. et al. (eds.) 1992. Ecophysiology of short rotation forest crops. New York : Elsevier Science, 1992, 308 p. ISBN 1-85166-848-9.

ROWE, R. - STREET, N. - TAYLOR, G. 2009. Identifying potential environmental impacts of large-scale deployment of dedicated bioenergy crops in the UK. In Renewable and Sustainable Energy Reviews, vol. 13, 2009, no. 1, pp. 271-290.

SHMÚ. 2010. Meteorologické údaje [elektronická pošta]. Správa pre: Martin HAUPTVOGL. 2010-02-18 [cit. 2010-02-19]. Osobná komunikácia.

SKLADAN, B. 2010. Produkčná a energetická bilancia rýchlorastúcich kultivarov rodu Salix v pôdnoekologických podmienkach južného Slovenska : dizertačná práca. Nitra : SPU, 2010, $131 \mathrm{~s}$.

STACKEVIČIENĖ, E. - MATELIS, A. - GRIGALIŪNAITĖ, B. 2010. Cultivation of the introduced Salix plants in plantations. In Acta Biol. Univ. Daugavpil., vol. 10, 2010, no. 2, pp. 173-176.

STEPHENS, W. - HESS, T. - KNOX, J. 2001. Review of the effects of energy crops on hydrology: Report. Silsoe : Institute of Water and Environment, Cranfield University, 2001, $59 \mathrm{p}$.

ŠPÁNIK, F. a i. 2008. Biometeorológia. Nitra : SPU, 2008, 227 s. ISBN 978-80-552-0068-2.

TSÚP. 2007. Akčný plán rozvoja biomasy: záverečná správa [online]. Rovinka: TSÚP, 38 s. [cit. 2010-05-11]. Dostupné na internete: <http://www.tsup.sk/files/zvs_5.pdf>.

TSÚP. 2009.Využitie polnohospodárskej biomasy na energetické účely a jej vplyv na trvaloudržatel'ný rozvoj: záverečná správa [online]. Rovinka : TSÚP, 95 s. [cit. 2013-20-06]. Available at: <http://www.tsup.sk/files/zvs_2.pdf >.

\section{Contact address:}

Martin Hauptvogl, Slovak University of Agriculture in Nitra, Department of Sustainable Development 